\title{
SCLERODERRIS LAGERBERGII GREMMEN, A NEW THREAT TO NURSERIES IN NORTHERN ONTARIO
}

\author{
BY DAVID PUNTER ${ }^{1}$
}

Oxf. 172.8

\section{ABSTRACT}

The occurrence of Scleroderris lagerbergii Gremmen on Pinus ssp. in and near Northern Ontario nurseries is reported. Symptoms and damage are described. Sanitation in the neighbourhood of nurseries is advocated as a first step in control.

\section{RESUME}

L'auteur rapporte la présence de Scleroderris lagerbergii Gremmen sur les pins dans certaines pépinières du centre et du nord de l'Ontario, puis il décrit les symptômes produits par ce champignon et évalue les dommages qu'il a causés. D'après l'auteur, une première mesure préventive devrait consister en la coupe et le brûlage des arbres déjà malades et croissant à proximité des pépinières.

\section{INTRODUCTION}

Since this organism was first described by Lagerberg (1913) on Norway spruce (Picea excelsa Link) under the name Crumenula abietina, it has come to be recognized as a dangerous pathogen of many coniferous species in Europe. It has caused serious losses of Scots pine (Pinus sylvestris $\mathbf{L}$.) seedlings in Swedish nurseries (Kohh, 1964)

Until very recently records from North America have been few, but a collection (MFB 6724) on white pine (Pinus strobus L.) made in Haughton Township, Sault Ste Marie Dist., Ontario as long ago as 1960 was identified by Dr. J. Reid ${ }^{2}$ as $S$. lagerbergii. Jorgensen ${ }^{3}$, while working for the Department of Forestry during 1962, found that mycelial inoculum, inserted into twigs of red pine (Pinus resinosa Ait.) could produce dieback and canker symptoms which corresponded with the spontaneous damage at Kirkwood Management Unit. More recently this pathogen has come under intensive study in the Lake States (Ohman, 1966) where it has been implicated in the condition known previously as "Jones' disease".

\section{SYMPTOMS AND OCCURRENCE}

During the spring of 1965 the author's attention was drawn to some brown patches in $2 / 0$ and $3 / 0$ red pine beds at Kirkwood Nursery. These same beds had appeared healthy and well-stocked immediately after disappearance of the snow cover. By the second week in May the needles of infected seedlings appeared to be drying out and had taken on a greyishgreen colour. When the new flush of growth began, their apical buds failed

\footnotetext{
${ }^{I}$ Research Scientist, Ontario Region, Department of Forestry \& Rural Development, stationed at Forest Research Laboratory, Maple, Ontario.

${ }^{2}$ Formerly Mycologist, Deparment of Forestry, Maple, Ontario; present address, Department of Botany, University of Manitoba, Winnipeg, Manitoba.

${ }^{3}$ Personal communication, Prof. E. Jorgensen, University of Toronto, Toronto 5, Ontario.
} 
to break and the previous year's needles turned brown, usually from the base. Patches increased in number as the season advanced and often enlarged radially to a diameter of $0.5-1.0 \mathrm{~m}$. Symptoms continued to appear until mid-June but after that time no further mortality was noted. Patches were more numerous in $3 / 0$ than $2 / 0$ and in exposed beds than in those close to the surrounding forest. At the centres of the patches in $3 / 0$ beds, one or more small dead seedlings were found. These apparently had died during the previous summer and served as foci for secondary infection. Their needles and stems bore pycnidia of Brunchorstia pinea (Karst.) Höhnel $(=B$. destruens Erikss.), an imperfect form of $S$. lagerbergii. (Since doubt has sometimes been cast on the connection between these forms, it should be noted that ascospores of $S$. lagerbergii from Kirkwood gave rise to pycnidia and spores in culture which corresponded with those taken from diseased seedlings). Tissue isolations from the advancing edge of infection also yielded the characteristic greenish, cottony mycelium from which pycnidia later arose. Another characteristic of this disease was the ease with which the bark of moribund seedlings separated from the wood. The disorganized tissues of the inner bark and outer wood frequently acquired a yellow- to dark-green discoloration. Small lesions were sometimes found in the bark of $3 / 0$ seedlings at the level of the first whorl of branches suggesting that infection had originated in one of these. The disease resulted in the loss of approximately 900,000 red pine seedlings from Kirkwood Nursery in 1965.

Diseased 3/0 red pine seedlings, collected on 10 May 1965 at Burt Township Nursery, Swastika District and sent to the author for examination, bore similar symptoms. Various combinations of $B$. pinea pycnidia, stem lesions, and green stain were found. Wood chips incubated at $15^{\circ} \mathrm{C}$ on $1.5 \%$ malt extract agar yielded characteristic cultures in seven out of ten cases. Provided that isolations were made from recently invaded tissues, special techniques such as Ohman (1966) has described were unnecessary. However, saprophytic organisms quickly overran chips from long-dead tissues under the same conditions.

So far as the author is aware these are the first confirmed reports of this disease in North American forest nurseries. Data in Table 1 indicate that infected stock was shipped from Kirkwood nursery in 1965. Seedlings from the two sources formed part of a randomized block experiment at Kirkwood and received identical treatments. High percentage mortality of newly planted red pine for several years is strong evidence that infection in nursery beds is not a new occurrence at Kirkwood.

While conducting other investigations during the fall of 1965 the author noticed symptoms resembling those at Kirkwood in other locations. Apothecia of $S$. lagerbergii were found on diseased 5-10 year-old red pines at Dorion, Thunder Bay District and at the Longlac nursery of Kimberly Clark Pulp \& Paper Co. Pyenidia and green bark-stain were also detected on severely damaged Scots pine at this nursery and on natural regeneration jack pine (Pinus banksiana Lamb.) in a cutover near Geraldton. In 1966, S. lagerbergii has again caused mortality in nursery beds of red pine and white pine at Kirkwood and of jack pine at Swastika. In addition, $B$. pinea has been 
TABLE 1

FATE OF RED PINE SEEDLINGS FROM TWO NURSERIES FIVE MONTHS AFTER OUTPLANTING* AT KIRKWOOD MANAGEMENT UNIT

\begin{tabular}{lcccc}
\hline \multirow{2}{*}{ Origin } & \multicolumn{3}{c}{ Number of seedlings } \\
\cline { 2 - 4 } \cline { 3 - 4 } & Planted & \multicolumn{2}{c}{ Dead } \\
\hline Kirkwood nursery & & Total & S. lagerbergii \\
Midhurst nursery & 900 & 110 & 37 \\
\hline
\end{tabular}

* Date of outplanting $17 \mathrm{May}, 1965$.

recorded from red pine at the Fauquier Township Nursery of Spruce Falls Power \& Paper Co.

The occurrence of this organism in or near so many major nurseries in northern Ontario must be a cause for concern. It is probably indigenous, a premise borne out by an intensive survey which has revealed several records on natural jack pine stands during $1966 .{ }^{4}$ In Sweden, Kohh (1964) considers that $S$. lagerbergii only reaches epidemic proportions when climatic conditions are favourable and the presence of diseased and dead pines or slash allows a marked build-up of inoculum. It is therefore imperative to avoid planting diseased seedlings as this will not only result in understocked plantations of cankered trees but will also provide new sources of inoculum. Because first symptoms continue to appear until mid-June in an average year, culling at the time of lifting will not necessarily remove all infected trees. Steps must therefore be taken to prevent infection in nursery beds.

\section{CONTROL}

The relative significance of asco- and pycnospores in infection and the means by which they spread are not entirely clear. However, observations on diseased patches in nursery beds suggest that pycnospores account for most secondary spread while ascospores may be important in establishment of new foci and long range dispersal. Whatever the means of spread it is clearly unsound to plant susceptible species (especially pines and spruces) in nursery shelter belts or to leave diseased trees in the surrounding forest. Such material has obviously provided a reservoir of inoculum at Kirkwood, Swastika, and Longlac nurseries. The first step in control must be sanitation by removal and burning of diseased trees from the neighbourhood of nurseries.

On chemical control of nursery beds, Kohh (1964) has found that good results may be obtained by spraying pine seedlings with maneb $(0.7-1.0 \%$ active ingredient in water with 1:2,000 wetting agent) at 2-week intervals, beginning 3-4 weeks after emergence. The spray should be applied at high pressure (over $200 \mathrm{psi}$ ) from nozzles maintained at $20 \mathrm{~cm}$ above the foliage.

Evaluation of maneb and other fungicides is proceeding in Ontario and the etiology of the disease is being studied. Until more information is available it is recommended that sanitation measures be used and seeding of red pine

\footnotetext{
"Personal communication, Mr. B. W. Dance, Research Scientist, Forest Insect and Disease Survey, Ontario Region, Department of Forestry \& Rural Development, Maple, Ontario.
} 
in northern Ontario nurseries be suspended. A manuscript dealing with the morphology, taxonomy, and some aspects of the physiology of this organism is in preparation.

\section{ACKNOWLEDGEMENTS}

The author wishes to thank Mr. J. D. Cafley for technical assistance and the staff of the Forest Disease Survey, Ontario Region who have contributed in many ways to this study.

\section{LITERATURE CITED}

KOHH, E. 1964. Om tallens gren- och granens topptorka och dess bekämpning. Skogen 51: 200-203.

LAGERBERG, T. 1913. Granens topptorka. Meddn St. skogsförsAnst. 10: 9-44.

OHMAN, J. H. 1966. Scleroderris lagerbergii Gremmen: The cause of dieback and mortality of red and jack pines in Upper Michigan plantations. Plant Disease Reptr. 50: 402-405. 